\title{
How Does the Five-year Plan Promote China's Economic Development?
}

\author{
Hongzhi TIAN and Hui LI* \\ Northwest University, Xi'an, China; nwuthz@nwu.edu.cn; nwulihui@163.com \\ * Corresponding author: nwulihui@163.com
}

\begin{abstract}
The main feature of socialist market economy with Chinese characteristics is that the development of national economy is planned. Through sorting out the development history of the 13 five-year plans, this paper finds that the planning is popular among the public, the planning context is historic inheritance, the planning objectives are logical progressiveness, and the planning implementation is practical and exploratory. The role of the five-year plan in China's economic development is reflected in the following aspects: first, the proposal of the five-year plan is targeted to China's economic reality. Second, the five-year plan can promote China's economic development. Third, the historical experience of the five-year plan has implications for China's economic future. The enlightenment is that we should respect the objective economic law as the premise, take firm and practical asymptotic development as the principle, take the pace of seek improvement in stability reform as the rhythm, take scientific and powerful policy measures as the guarantee, and take the path of building a new pattern of domestic and international double circulation.
\end{abstract}

Keywords: five-year plan; China's economic development; domestic and international double cycle

JEL Classification: O10; O11; O21

\section{Introduction}

Since the founding of the People's Republic of China, social progress has been made, people's living standards have been significantly improved, and China's economy has achieved great development. The five-year plan is a key to understand the miracle of China's development. It is not only an important tool for creating China's economic miracle and maintaining macro stability, but also an important tool for promoting social development and facilitating the transformation of China's development model (Hu et al., 2011). As the most characteristic national economic operation and social development management tool in China, the five-year plan can reflect the development history of China's socialist economy and has made an important contribution to China's glorious economic achievements and the overall building of a moderately prosperous society. This paper hopes to derive the successful experience of China's economy from the evolutionary logic of the five-year plan and provide lessons for the development of the world economy. 


\section{The Development History of the Five-year Plan of New China}

After years of war, New China was faced with a shattered economy with a deformed development structure and a disrupted market. In order to repair the severely damaged productivity and make material and institutional preparations for the fiveyear plan in the Party Central Committee defined the period from 1949 to 1952 as a period of national economic recovery. The rural areas completed the land reform, and farmers obtained about 700 million mu of land and a large amount of production materials without compensation. The city carried out the reform of enterprise management system and property right relationship, and began to establish stateowned economy. On this basis, the 1st Five-year Plan was implemented in 1953. With the aid of the former Soviet Union, China carried out the basic construction of socialist industrialization and completed the socialist transformation of agriculture, handicraft industry and private industry and commerce at the same time, which laid the foundation of China's socialist economy.

The 2nd Five-year Plan was guided by the policy of "more speed, better savings," and although the production of iron and steel soared, due to the imbalance of resource allocation and economic structure, some light industrial products supply has problems. Due to the break-up of Sino Soviet relations and the sudden change of the international environment such as the U.S. invasion of Vietnam. During the period of the 3rd Fiveyear Plan and the 4th Five-year Plan, China's national defense industry has made great progress. Due to the excessive investment in the "Third Line Construction", the total demand of the society swelled and led to the disproportion of the economy. The 5th Five-year Plan has made great efforts to turn the tide, re-establish the ideological line of seeking truth from facts, and shift the focus to socialist modernization construction in time.

The 6th Five-year Plan carefully summed up the experience of the previous construction period, made an overall plan for major national construction projects and productivity distribution (Yang,2019), and put forward the guiding ideology of "all economic activities should focus on improving economic benefits" (National People's Congress,1982). During the period of the 7th Five-year Plan, planned economy and planned commodity economic system coexisted. From 1988 to 1989, the price double track system opened a new chapter in China's economic system reform and played a prelude to the transformation of economic development strategy and economic management system to a new model.

The 14th National Congress of the Communist Party of China (CPC) held during the 8th Five-year Plan period officially set the establishment of socialist market economic system as the goal of reform. The socialist market economic system has been gradually established. During the 9th Five-year Plan period, "the economic system has changed from the traditional planned economic system to the socialist market economic system, 
and the mode of economic growth has changed from extensive type to intensive type" (National People's Congress, 1996).

The 10th Five-year plan put forward more targeted goals, such as strategic adjustment of economic structure, significant improvement of economic growth quality and efficiency, and the traditional "directive plan" begins to withdraw from the economic system. The average annual growth rate of GDP from 2002 to 2007 is $11.9 \%$, which is the longest period of economic growth after the reform and opening up (Ma, 2018). As early as 2008, most of the tasks of the main indicators of the 11th Five-year Plan were completed. Two years later, China's GDP rose to the second place in the world. In the aftershocks of the international financial crisis, there are still some problems in China's economic and social development, such as imbalance, uncoordinated and unsustainable. Therefore, the 12th Five-year Plan pointed out that we should take scientific development as the theme, relying on science and technology and human capital growth to drive economic growth. As China's economic development entering the new normal, with the new development concept of "Innovation, Coordination, Green, Open and Sharing", and the main line of supply side structural reform, the 13th Five-year Plan proposed to coordinate the overall layout of "Five-in-One" and "Four Comprehensives" to ensure the realization of the goal of building a moderately prosperous society in an all-round way.

We summarize the 13 five-year plans in Table 1, based on the historical role they have played.

Table 1. The historical role of the 13 five-year plans

\begin{tabular}{|l|l|l|}
\hline Five-year plan & $\begin{array}{l}\text { Starting and } \\
\text { ending years }\end{array}$ & Historical role played \\
\hline the 1st Five-year Plan & $1953-1957$ & Laying a solid foundation for socialist economy. \\
\hline the 2nd Five-year Plan & $1958-1962$ & Eager for a leap forward period. \\
\hline the 3rd Five-year Plan & $1966-1970$ & War risk preparation period. \\
\hline the 4th Five-year Plan & $1971-1975$ & War risk preparation period. \\
\hline the 5th Five-year Plan & $1976-1980$ & $\begin{array}{l}\text { Guiding ideology and economic policy recovery and } \\
\text { adjustment period. }\end{array}$ \\
\hline the 6th Five-year Plan & $1981-1985$ & The turning point of development strategy. \\
\hline the 7th Five-year Plan & $1986-1990$ & Incubation period of economic system reform. \\
\hline the 8th Five-year Plan & $1991-1995$ & The construction period of socialist market economic system. \\
\hline the 9th Five-year Plan & $1996-2000$ & $\begin{array}{l}\text { Complete the three-step strategic goal, carry forward the past } \\
\text { and start the later stage. }\end{array}$ \\
\hline the 10th Five-year Plan & $2001-2005$ & $\begin{array}{l}\text { Key period for completing the third step of strategic } \\
\text { objectives. }\end{array}$ \\
\hline the 11th Five-year Plan & $2006-2010$ & $\begin{array}{l}\text { The coexistence period of strategic opportunities and } \\
\text { contradictions. }\end{array}$ \\
\hline the 12th Five-year Plan & $2011-2015$ & $\begin{array}{l}\text { Accelerating the transformation of the mode of economic } \\
\text { development. }\end{array}$ \\
\hline the 13th Five-year Plan & $2016-2020$ & $\begin{array}{l}\text { Decisive period of building a moderately prosperous society } \\
\text { in all respects. }\end{array}$ \\
\hline
\end{tabular}

${ }^{1}$ Note: $1963-1965$ was a three-year adjustment period. 


\section{The Basic Features of the Five-year Plan}

Using development planning to guide economic and social development is an important way for China's Party to govern the country. Development planning can give full play to the decisive role of the market in the allocation of resources, but also to better play the role of the government. The basic features of the five-year plan are as follows.

\subsection{The Five-year Plan Shows the History Inheritance}

China's 13 five-year plans have realized the national overall development strategy with the longest time, the largest scale and the largest number of participants in human history. The fundamental reason for achieving the above record is that the Party Central Committee accurately grasped the process and strategic steps of China's economic and social development, and local governments at all levels earnestly implemented the fiveyear plans. The domestic economic and social development level has achieved unprecedented development in the past 70 years since the founding of New China, despite the great changes in the international environment. It can be seen that only when the domestic environment is stable, the development line is firm and the implementation is firm, can the five-year plan realize long-term historical inheritance.

\subsection{The Goal of the Five-year Plan Shows a Logical Progression}

As can be seen from Table 1, although the five-year plan has different construction tasks in each period, vertically, there is a logical progression between the development goals of the five-year plan. Specifically, from the 3rd Five-year Plan to solve the basic survival problems of people's "food, clothing and use", to the 9th Five-year Plan to reach the "well-off level" in advance, and then to the 13th Five-year Plan to build a well-off society in an all-round way, it reflects the logical progression of people's living standards. From the development of a planned economy in the first five plans to a planned commodity economy in the 7th Five-year Plan, and then to the fundamental role of the market economy in the 9th Five-year Plan, the change to the decisive role of the market in the 12th Five-year Plan, which reflects the logical progression of the evolution of the economic system. From the basic solution of survival problems in the 3rd Five-year Plan to the focus on the construction of material civilization in the 6th Fiveyear Plan, and then to strengthening the construction of spiritual civilization in the 8th Five-year Plan, it reflects the logical progressive nature of human demand level.

From the 2nd Five-year Plan, which focused only on the development of heavy industry, to the 5th Five-year Plan, which improved the disproportionate relationship between accumulation and consumption in the national economy, to the 8th Five-year Plan, which proposed a fundamental change in the mode of economic growth from a sloppy to an intensive mode, then to the 13th Five-year Plan, which proposed a green development concept of harmony between human beings and nature, showing the logical progression of economic development mode. From the "more, faster and better 
province" in the 2nd Five-year Plan and the blind pursuit of high index construction policy in the 3rd Five-year plan, to the development thought of being eager for success in the 7th Five-year Plan, to the sustainable development concept in the 10th Five-year Plan, and then to the coordinated development concept in the 13th Five-year Plan, it reflects the logical progression of the concept of governing the country.

\subsection{The Compilation of the Five-year Plan Reflects the Wide Range of Public Opinion}

Through extensive discussions, revisions and improvements during the formulation process, the five-year plan has become increasingly scientific, democratized and standardized (Huang, 2020). In April 2014, a teleconference was held in Beijing to prepare the 13th Five-year Plan, and the National Development and Reform Commission promulgated 25 major topics to carry out preliminary work such as basic investigation, information collection, subject research and project demonstration. In February 2015, the central government set up a drafting group for the 13th Five-year Plan to conduct intensive research with the National People's Congress, the National Committee of the Chinese people's Political Consultative Conference (CPPCC) and various democratic parties, soliciting opinions extensively, and forming 117 special studies. Then, the draft of the 13th Five-year Plan outline was sent to all provinces, autonomous regions, municipalities directly under the central government and the central government departments for extensive consultation.

As we can see, the process of introducing the five-year plan actually reflects the real needs and specific suggestions of all sectors of society, and the outline of the plan reflects the greatest social consensus, expresses the development will of the whole nation, and forms the spiritual roadmap on the road of China's development.

\subsection{The Five-year Planning Process Reflects the Exploratory Nature of Economic Practice}

From the 1st Five-year Plan to the 5th Five-year Plan, the starting point of the Party and the government's economic work was to establish a highly centralized socialist planned economic system, with less use of market instruments to regulate the operation of the national economy at the micro level. Until the end of the 5th Five-year Plan, with the deepening understanding of the law of economic operation by the party and the government, the national economic management means gradually explored the resource allocation mode with planned economy as the main factor and market regulation as the supplement from the 6th Five-year Plan.

The 14th Party Congress during the 8th Five-year Plan proposed that "the market plays a fundamental role in the allocation of resources under the macro-control of socialist countries" (National People's Congress, 1991). At this time, the market as a basic means of resource allocation has been recognized, and the corresponding policy objectives of the five-year plan have changed from mandatory plan to guiding plan.

Furthermore, the core position of property rights was clarified during the 10th Five-year Plan period. The 11th Five-year Plan emphasized that the government 
should play an increasingly important role in ecological and environmental protection, regional coordinated development, urban-rural relations, development of science, education, culture and health, social security and public services. The 12th Five-year Plan emphasized that "economic system reform is the key to comprehensively deepen the reform, and the core issue is to properly handle the relationship between the government and the market, so that the market can play a decisive role in the allocation of resources and give better play to the role of the government" (National People's Congress, 2013). So far, the relationship between the government and the market has been clearly defined, and is committed to the realization of an effective market and a responsive government.

It can be seen that the practice process of the five-year plan is also the process of the Party's continuous exploration for the laws of socialist economic development, especially the understanding of the relationship between plan and market, government and market is full of tortuous exploration.

\section{China's Economic Development During the Five-year Planning Period}

Since the implementation of the five-year plan, China's economy has made considerable progress. Table 2 summarizes the statistical data of China's total GDP and per capita GDP at the end of each five-year plan, as well as the proportion of China's GDP in the world.

Table 2. Changes in China's GDP and its position in the world

\begin{tabular}{|l|c|c|c|c|}
\hline Five-year plan & $\begin{array}{c}\text { Year at the end of the } \\
\text { planning period }\end{array}$ & $\begin{array}{c}\text { GDP (US \$100 } \\
\text { million) }\end{array}$ & $\begin{array}{c}\text { GDP per capita } \\
\text { (USD) }\end{array}$ & $\begin{array}{c}\text { Global share of } \\
\text { GDP }\end{array}$ \\
\hline the 1st Five-year Plan & 1957 & 975.87 & 153.12 & -- \\
\hline the 2nd Five-year Plan & 1962 & 879.31 & 132.07 & $0.70 \%$ \\
\hline the 3rd Five-year Plan & 1970 & $1,869.94$ & 228.51 & $0.97 \%$ \\
\hline the 4th Five-year Plan & 1975 & $2,491.03$ & 271.82 & $1.07 \%$ \\
\hline the 5th Five-year Plan & 1980 & $3,406.06$ & 347.12 & $1.22 \%$ \\
\hline the 6th Five-year Plan & 1985 & $5,649.37$ & 537.50 & $1.78 \%$ \\
\hline the 7th Five-year Plan & 1990 & $8,277.32$ & 729.16 & $2.18 \%$ \\
\hline the 8th Five-year Plan & 1995 & $14,757.65$ & $1,224.84$ & $3.50 \%$ \\
\hline the 9th Five-year Plan & 2000 & $22,321.46$ & $1,767.83$ & $4.47 \%$ \\
\hline the 10th Five-year Plan & 2005 & $35,619.79$ & $2,732.16$ & $6.13 \%$ \\
\hline the 11th Five-year Plan & 2010 & $60,871.65$ & $4,550.45$ & $9.21 \%$ \\
\hline the 12th Five-year Plan & 2015 & $89,133.17$ & $6,500.28$ & $11.74 \%$ \\
\hline the 13th Five-year Plan & 2019 & $115,371.60$ & $8,254.30$ & $13.58 \%$ \\
\hline
\end{tabular}

${ }^{1}$ Note: The global share of China's GDP in 1957 is not available, because World Bank statistics on national GDP start from 1960. The data in the table are all calculated in constant 2010 U.S. dollars. The values at the end of the 13th Five-Year Plan period are expressed as 2019 data in this paper.

As can be seen from Table 2, China's GDP at the end of the 2nd Five-year Plan was only US\$87.931 billion, and the GDP per capita was only US\$132.07, which was less than $1 \%$ of the global GDP of the Eastern powers and ranked 20th in the world. Happily, China's GDP exceeded US\$6 trillion in 2010, the year of the 11th Five-year 
Plan. Then, China's economy reached $11.74 \%$ of global GDP in 2015 and continues to grow. By 2019, China's GDP per capita had reached US\$8,254.30, and people's living standards had improved significantly. In 2020, China's total GDP has exceeded RMB 100 trillion, showing resilience in economic development even in the face of the COVID-19 epidemic.

Table 3. World ranking of GDP in five-year intervals

\begin{tabular}{|c|c|c|c|c|c|c|c|c|c|c|c|c|}
\hline Rank & 1960 & 1965 & 1970 & 1975 & 1980 & 1985 & 1990 & 1995 & 2000 & 2005 & 2010 & 2015 \\
\hline 1 & USA & USA & USA & USA & USA & USA & USA & USA & USA & USA & USA & USA \\
\hline 2 & UK & France & Germany & Japan & Japan & Japan & Japan & Japan & Japan & Japan & China & China \\
\hline 3 & France & UK & Japan & Germany & Germany & Germany & Germany & Germany & Germany & Germany & Japan & Japan \\
\hline 4 & China & Japan & France & France & France & France & France & France & UK & UK & Germany & Germany \\
\hline 5 & Japan & China & UK & UK & UK & UK & Italy & UK & France & China & France & UK \\
\hline 6 & Canada & Italy & Italy & Italy & Italy & Italy & UK & Italy & China & France & UK & France \\
\hline 7 & Italy & India & China & Canada & Canada & Canada & Canada & Brazil & Italy & Italy & Brazil & India \\
\hline 8 & India & Canada & Canada & China & Brazil & China & Spain & China & Canada & Canada & Italy & Italy \\
\hline 9 & Australia & Argentina & India & Brazil & Spain & India & Russia & Spain & Mexico & Spain & India & Brazil \\
\hline 10 & Brazil & Australia & Brazil & Spain & Mexico & Brazil & Brazil & Canada & Brazil & Korea & Canada & Canada \\
\hline
\end{tabular}

${ }^{1}$ Note: Data are from the World Bank.

Table 3 shows the GDP ranking of each country according to the current price of US dollar. From this table, we can see that first, China's GDP ranking in the world basically shows a "V" shaped trend, i.e., in 1960, the total economic volume ranked fourth in the world, but with the rapid economic development of Japan, Italy and other countries, China's ranking gradually moved backward. In the 1980s and 1990s, China briefly fell out of the top ten positions in the world. Since 1995, China's ranking has gradually risen, and in 2006 it overtook the United Kingdom, in 2007 it overtook Germany, and in 2010 it overtook Japan, achieving a triple jump to second place in the world, and it has remained there ever since.

\section{How Does the Five-year Plan Promote China's Economic Development?}

Although the role of the government in economic development is different between the planned economy and the market economy. The socialist market economy system in China determines the dominance of the Party and the government in the formulation and implementation of the five-year plan, which inevitably brings about the promotion of the five-year plan to China's economic development. In the following, this paper provides an in-depth analysis of how the five-year plan promotes China's economic development. 
Table 4. Measures for economic problems in each period of the five-year plan

\begin{tabular}{|c|c|c|}
\hline Five-year plan & $\begin{array}{l}\text { The current economic situation at } \\
\text { that time }\end{array}$ & Strategic measures given in the five-year plan \\
\hline $\begin{array}{l}\text { the 1st Five- } \\
\text { year Plan }\end{array}$ & $\begin{array}{l}\text { Weak industrial base and weak } \\
\text { state-owned economy. }\end{array}$ & $\begin{array}{l}\text { To drive the overall construction with big projects, } \\
\text { and to lay down and develop China's socialist } \\
\text { industrial system with foreign aid as an auxiliary } \\
\text { measure. }\end{array}$ \\
\hline $\begin{array}{l}\text { the 2nd Five- } \\
\text { year Plan }\end{array}$ & $\begin{array}{l}\text { The "Great Leap Forward" } \\
\text { Movement. }\end{array}$ & $\begin{array}{l}\text { In 1960, the policy of "adjustment, consolidation, } \\
\text { enrichment and improvement" was introduced to } \\
\text { correct and rectify the situation. }\end{array}$ \\
\hline $\begin{array}{l}\text { the 3rd Five- } \\
\text { year Plan }\end{array}$ & Risk of external war. & $\begin{array}{l}\text { Take national security as the starting point, adjust } \\
\text { the national industrial layout and tend to the old, } \\
\text { small and poor areas for economic construction. }\end{array}$ \\
\hline $\begin{array}{l}\text { the 4th Five- } \\
\text { year Plan }\end{array}$ & $\begin{array}{l}\text { Too high front-end target and too } \\
\text { large infrastructure. }\end{array}$ & $\begin{array}{l}\text { Put forward the task of accelerating the development } \\
\text { of light industry and promoting the comprehensive } \\
\text { balance of the national economy. }\end{array}$ \\
\hline $\begin{array}{l}\text { the } 5 \text { th Five- } \\
\text { year Plan }\end{array}$ & $\begin{array}{l}\text { The national economy was } \\
\text { devastated by political turmoil and } \\
\text { the "leftist" erroneous ideology of } \\
\text { seeking success in a hurry. }\end{array}$ & $\begin{array}{l}\text { Re-establish the ideological line of "seeking truth } \\
\text { from facts" and shift the focus of work to socialist } \\
\text { modernization. }\end{array}$ \\
\hline $\begin{array}{l}\text { the 6th Five- } \\
\text { year Plan }\end{array}$ & $\begin{array}{l}\text { The level of economic development } \\
\text { lags behind and people's living } \\
\text { standards are not high. }\end{array}$ & $\begin{array}{l}\text { Establish the policy that "all economic activities } \\
\text { should be centered on improving economic } \\
\text { efficiency" and the strategic goal of quadrupling the } \\
\text { annual gross output value of industry and } \\
\text { agriculture by the end of the 20th century. }\end{array}$ \\
\hline $\begin{array}{l}\text { the } 7 \text { th Five- } \\
\text { year Plan }\end{array}$ & Economic overheating, inflation. & $\begin{array}{l}\text { Carried out efforts to reform the economic system } \\
\text { and promote a linear paradigm shift in economic } \\
\text { development strategies and economic management } \\
\text { systems. }\end{array}$ \\
\hline $\begin{array}{l}\text { the 8th Five- } \\
\text { year Plan }\end{array}$ & $\begin{array}{l}\text { China's reform enters crossroads, } \\
\text { ideological rigidity under dramatic } \\
\text { changes in Eastern Europe. }\end{array}$ & $\begin{array}{l}\text { Emancipate the mind, "be more daring in reform and } \\
\text { opening up", and make the establishment of a } \\
\text { socialist market economy system the goal of reform. }\end{array}$ \\
\hline $\begin{array}{l}\text { the 9th Five- } \\
\text { year Plan }\end{array}$ & $\begin{array}{l}\text { Low economic efficiency of } \\
\text { enterprises, the existing economic } \\
\text { system does not adapt to the } \\
\text { requirements of the development } \\
\text { of socialist market economy. }\end{array}$ & $\begin{array}{l}\text { Put forward the "economic system from the } \\
\text { traditional planned economic system to the socialist } \\
\text { market economic system, economic growth from the } \\
\text { sloppy to intensive transformation", giving nine } \\
\text { important guidelines. }\end{array}$ \\
\hline $\begin{array}{l}\text { the 10th Five- } \\
\text { year Plan }\end{array}$ & $\begin{array}{l}\text { Backward production methods that } \\
\text { consume a lot of energy and } \\
\text { operate in a sloppy manner for } \\
\text { economic development. }\end{array}$ & $\begin{array}{l}\text { Propose strategies to strengthen ecological } \\
\text { construction, environmental protection and } \\
\text { sustainable economic and social development. }\end{array}$ \\
\hline $\begin{array}{l}\text { the 11th Five- } \\
\text { year Plan }\end{array}$ & $\begin{array}{l}\text { Imbalance of urban-rural and } \\
\text { regional development, insufficient } \\
\text { economic structure. }\end{array}$ & $\begin{array}{l}\text { Put forward the coordinated development of urban } \\
\text { and rural areas, accelerate the transformation of } \\
\text { economic growth, improve the ability of } \\
\text { independent innovation and other "six must" } \\
\text { principles. }\end{array}$ \\
\hline $\begin{array}{l}\text { the 12th Five- } \\
\text { year Plan }\end{array}$ & $\begin{array}{l}\text { Uneven and unsustainable } \\
\text { economic development. }\end{array}$ & Put forward the "five persistent" basic requirements. \\
\hline $\begin{array}{l}\text { the 13th Five- } \\
\text { year Plan }\end{array}$ & $\begin{array}{l}\text { The overlap of "growth rate shift } \\
\text { period, structural adjustment pain } \\
\text { period, the previous policy } \\
\text { digestion period", effective } \\
\text { demand and effective supply are } \\
\text { insufficient. }\end{array}$ & $\begin{array}{l}\text { Put forward the five major development concepts of } \\
\text { "innovation, coordination, green, openness and } \\
\text { sharing" to lead China to a moderately prosperous } \\
\text { society. }\end{array}$ \\
\hline
\end{tabular}




\subsection{The Proposal of the Five-year Plan is Targeted to China's Economic Reality}

As can be seen from the above table, the five-year plan has a very strong realistic relevance, and dares to face the shortcomings and difficulties in each development period, not avoiding the problems, facing up to them and giving scientific and wise response guidelines and strategic planning. The realistic relevance of the five-year plan makes it a powerful guarantee for China's economic growth and promotes the rapid and healthy development of China's economy (see Table 4).

\subsection{The Implementation of the Five-year Plan Tasks Has a Catalytic Effect on China's Economic Development}

Generally speaking, the implementation of the 13 five-year plans has promoted China's economy in the following aspects: the first five-year plans focused on building a socialist economic system, while the latter five-year plans focused on economic system reform, resulting in the increase of China's economic volume and the improvement of economic quality.

The five-year plan improved China's economic system and gradually formed a complete industrial system and national economic system. China's industrial base was weak at the beginning of the founding of New China, but after the "4th Five-year Plan", a relatively complete industrial system and national economic system were initially established. The five-year plans promoted the reform of China's economic system and realized the transformation of China from a planned economy, a planned commodity economy, to a socialist market economy. The five-year plans propelled China's economic expansion and a sharp rise in the world ranking of GDP. As seen in Part 4, China's GDP world ranking shows a "V" shaped trend and China has become an important engine of world economic development.

\subsection{The Historical Experience of the Five-year Plans Have Lessons for the Future of China's Economy}

Summarizing the experience and lessons learned from the previous 13 five-year plans can provide a clear understanding of China's current historical point and stage of development, so as to provide reference for the preparation of scientific and reasonable five-year plans, and set more strategic and feasible goals to promote the sustained and positive development of China's economy and society.

First, the setting of overly aggressive development goals should be prevented. Although the five-year plan drew on a wide range of recommendations in setting its goals, its implementation was sometimes influenced by certain factors that raised the original plan's targets and brought about adventurous behavior beyond the stage of economic development. For example, the 2nd Five-year Plan was based on the idea of high speed. During the 3rd Five-year Plan, the actual implementation of the plan was adjusted to "war preparation as the center" due to the breakdown of Sino-Soviet relations and national defense considerations. During the 4th Five-year Plan, the main focus was 
on the strategic rear construction of the "Great Third Front", which was characterized by high speed and high targets.

Second, the law of economic development should be respected and strong policy measures should be mastered. 1985-1988 price reform caused a sharp rise in prices and the emergence of "two prices for one product, resulting in planned products being left outside the plan, and outside the plan changing hands, with a large amount of national wealth falling into the pockets of private individuals and small groups" as predicted by Guo et al. (1985). The reasons for this are, the lack of understanding of the laws of the economic cycle, expectations were misguided at the time and inappropriate macro policy measures.

\section{Conclusion}

This paper compares the historical roles played by each of the five-year plans since the founding of New China. On this basis, the paper concludes that the five-year plan has shown historical inheritance, logical progression in their objectives, extensive public opinion in their preparation, and tortuous exploration in their practice. Further, the fiveyear plan has promoted China's economic development in the following ways. First, the five-year plan is relevant to China's economic reality. Second, the five-year plan is of great significance to China's economic development. Third, the historical experience of the five-year plan can be used for reference for the future development of China's economy. In the formulation and implementation of the next five-year plan, we should respect the objective economic laws as the premise, take the steady and steady progressive development as the principle, take the pace of reform as the rhythm, take the scientific and powerful policy measures as the guarantee, and take the construction of a new pattern of domestic and international dual circulation as the path to further improve the modern economic system proposed in the report of the 19th National Congress of the Communist Party of China.

\section{References}

Guo, S. Q., Liu, J., \& Qiu, S. (1985). Comprehensive reform needs master plan (in Chinese). Comparison of economic and social systems, 1, 21-26.

Hu, A. G., Yan, Y. L., \& Lv, J. (2011). An important means of China's development miracle -- Taking the transformation of the five-year plan as an example (from the sixth five year plan to the Eleventh Five Year Plan) (in Chinese). Journal of Tsinghua University (Philosophy and Social Sciences Edition), 26(01), 43-52. https://doi.org/10.13613/j.cnki.qhdz.001960

Huang, J. H. (2020). On the important characteristics and historical experience of the "Five Year Plan" (in Chinese). Economic Daily, 06-30(011). https://doi.org/10.28425/n.cnki.njjrb.2020.006181

Ma, J. T. (2018). Review and Prospect of China's development strategy (in Chinese). Managing the world, 34(10), 2-10. https://doi.org/ 10.19744/j.cnki.11-1235/f.2018.10.001

National People's Congress. (1982). The sixth five-year plan for national economic and social development of the people's Republic of China (in Chinese) (Bulletin of the Standing Committee of the National People's Congress, 1982). Standing Committee of the National People's Congress. http://www.npc.gov.cn/wxzl/gongbao/1982-11/30/content_1478459.htm 
National People's Congress. (1991). Ten year plan for national economic and social development of the people's Republic of China and outline of the Eighth Five Year Plan (in Chinese) (Bulletin of the Standing Committee of the National People's Congress, 1991). Standing Committee of the National People's Congress. http://www.npc.gov.cn/wxzl/gongbao/2000-12/28/content_5002538.htm

National People's Congress. (1996). The Ninth Five Year Plan for national economic and social development of the people's Republic of China and the outline of long term goals for 2010 (in Chinese) (Bulletin of the Standing Committee of the National People's Congress, 1996). Standing Committee of the National People's Congress. http://www.npc.gov.cn/wxzl/gongbao/2001-01/02/content_5003506.htm

National People's Congress. (2013). Decision of the Central Committee of the Communist Party of China on several major issues of comprehensively deepening reform (in Chinese) (Bulletin of the Standing Committee of the National People's Congress, 2013). Standing Committee of the National People's Congress. http://www.gov.cn/jrzg/2013-11/15/content_2528179.htm

Yang, W. M. (2019). Reform the planning system and give full play to the guiding role of planning strategy (in Chinese). China Administration, 8, 6-8. 